\title{
Uterine Gland Microstructure in the Pregnant and the Non-pregnant Lesser Galago (Galago senegalensis)
}

\author{
Microestructura de la Glándula Uterina en la Gálago Menor \\ (Galago senegalensis) Preñada y No Preñada
}

Allan Njogu*; George Otiang'a Owiti,*** \& Dominic Oduor-Okelo*

NJOGU, A.; OWITI, G. O. \& ODUOR-OKELO, D. Uterine gland microstructure in the pregnant and the non- pregnant lesser galago (Galago senegalensis). Int. J. Morphol., 31(2):771-776, 2013.

SUMMARY: The histology and the ultrastructure of the uterine glands of the lesser bushbaby (Galago senegalensis) were studied in six specimens (5 pregnant and one non pregnant) which were fixed partly with bouin's fixative and part with $2.5 \%$ glutaraldehyde in $0.1 \mathrm{M}$ cacodylate buffer. An overview of the main results revealed uterine glands in the non-pregnant uterus are rudimentary and scarce within the mucosa. In early pregnancy (first trimester) the uterine glands profiles appear in clusters. In late stage pregnancy (third trimester) the uterine gland profiles appear opposite chorionic vesicles. In the later stages of gestation maternal glandular epithelium consisted mainly of simple columnar epithelium. The cells had abundant flattened cisternae of granular endoplasmic reticulum usually with an apical-basal orientation. Their nuclei had abundant euchromatin relative to the amount of heterochromatin. They also had a prominent Golgi apparatus quite characteristic of protein synthesizing cells. The basal plasmalemma was thrown into infoldings that have the effect of increasing the surface area across which nutrients could pass from the maternal circulation and are secreted by the cell as histiotrophe. Both physiologic hypertrophy and hyperplasia of the uterine glands are observed to occur with advancement of pregnancy.

KEY WORDS: Lesser bushbaby; Uterine gland; Microstructure.

\section{INTRODUCTION}

Gestation, in viviparous mammals, is the period of embryo and fetus development from the fusion of the female and male gametes (conception) to birth.

Histiotrophe is the nutritional material in spaces between the maternal and fetal tissues and is derived from the maternal tubal secretions, endometrium and the uterine glands. This nutritional material is absorbed by phagocytosis initially by blastocyst trophectoderm (Latham et al., 1999) and then by trophoblast of the placenta (Bevilacqua et al., 2010). In later placental development nutrition is by the exchange of blood-borne materials between the maternal and fetal circulations (hemotrophic nutrition) (Beck 1976). Histiotrophe represents an important source of nutrients for the developing embryo, as well as containing a variety of growth factors during the first trimester of pregnancy in the humans (Burton et al., 2002; Hempstock et al., 2004; Burton et al., 2007; Jones et al., 2010).

In the lower primates the trophoblast of the placental villi is engaged in both hemotrophic and histiotrophic nourishment of the fetus. Both histiotrophic and hemotrophic nutrition morphologically appear side by side throughout pregnancy. The uterine glands in the galago, open for the most part in groups, their openings being on depressed areas of the mucosa opposite chorionic vesicles which are specially modified absorptive areas of the chorion termed the chorionic vesicles. Chorionic vesicles are invaginations of the chorion opposite the mouths of the uterine glands (King, 1984; Njogu et al., 2006; Wooding \& Burton, 2008).

This report describes the ultrastructural detail of the structures involved in the one type of fetal nourishment (histiotrophic) seen in this species of primates i.e the uterine gland epithelium.

\section{MATERIAL AND METHOD}

Bush babies belong to the order Primate and the sub order; Prosimii (lower primates). A total of six female lesser bush

\footnotetext{
* Department of Veterinary Anatomy and Physiology, University of Nairobi, Nairobi, Kenya.

**Principal, Kenya Wildlife Service Training Institute, Naivasha, Kenya.
} 
babies were used in this study. Fixation of tissues was done both by injection and immersion to achieve good and thorough fixation especially for the early conceptus and placenta. Tissues from the later stage pregnancy were fixed for transmission electron microscopy while the non-pregnant and the early pregnancy uteri were fixed for histology. Fixatives used were either Bouin's or glutaraldehyde fixative (depending on whether the tissues were to be processed further for light or electron microscopy). 2.5\% glutaraldehyde mixture in $0.1 \mathrm{M}$ cacodylate buffer $(\mathrm{pH}=7.2)$ was used for electron microscopy whereas other tissue samples were fixed in Bouin's for routine histology.

The Bouin's solution fixed tissues were processed for routine histological sections. This involved dehydration through ascending concentrations of ethanol $(50 \%, 70 \%$, $90 \%$ and $100 \%$ ), clearing using methyl benzoate and infiltration and embedding in molten wax. The embedded tissues were then mounted on wooden blocks and $5 \mu \mathrm{m}$ thick sections cut with a sliding microtome. The sections obtained were subsequently stained with haematoxylin and eosin and examined for light microscopy studies.

Tissues fixed in $2.5 \%$ glutaraldehyde in $0.1 \mathrm{M}$ cacodylate buffer were subsequently diced, washed in $0.1 \mathrm{M}$ cacodylate buffer, post fixed in $2 \%$ osmium tetroxide for 2 hours at room temperature, dehydrated through ascending concentrations of ethanol (50\% for 15 minutes, 2 changes of $70 \%$ for 10 minutes each, 2 changes of $80 \%$ each for 15 minutes, 2 changes of $95 \%$ each for 15 minutes and finally 2 changes of $100 \%$ each for 30 minutes) and embedded in epon resin. Semi-thin sections were cut with glass knives on a Sorvall MT-1 'Porter Blum' microtome and stained with methylene blue or toluidine blue stain and examined with the light microscope for the purpose of tissue selection and orientation. Ultra-thin sections were cut with diamond knife (Diatomeâ) using an Ultra Reichert microtome. These were subsequently mounted on copper grids and double stained with uranyl acetate followed with lead citrate and examined with a Zeiss EM microscope.

\section{RESULTS}

The non-pregnant uterus is bicornuate with a small uterine body, about 1 centimeter in length. This is unlike that of higher primates which have a uterus simplex. The uterus is suspended on either side by an extensive and transparent mesometrium. The uterine wall is composed of an endometrium with numerous longitudinal folds, a myometrium and a perimetrium (Fig. 1). The folds are lined by a pseudo-stratified type of epithelium (Fig. 2).

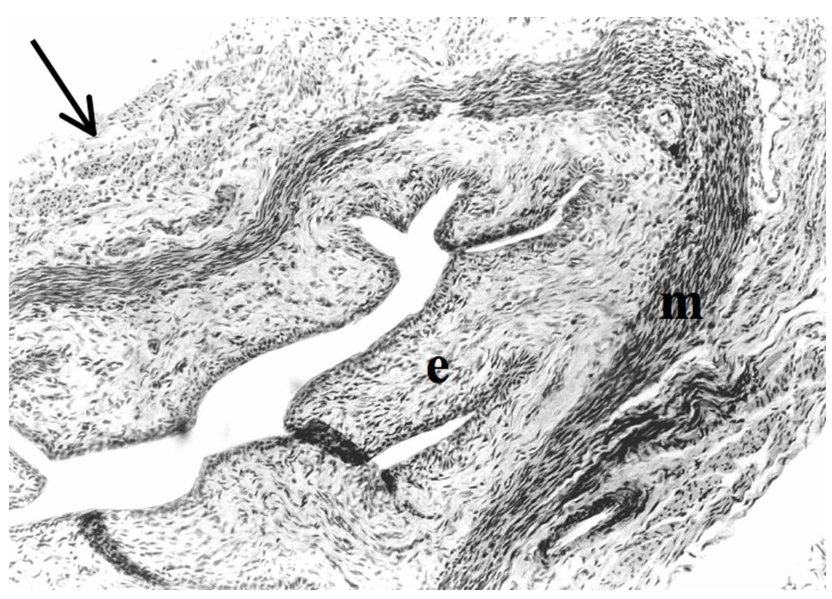

Fig. 1. A photomicrograph of a cross section of the non-pregnant uterine wall. Note the endometrium (e) with longitudinal folds, a myometrium (m) and a perimetrium (arrow). X 100. H-E stain.

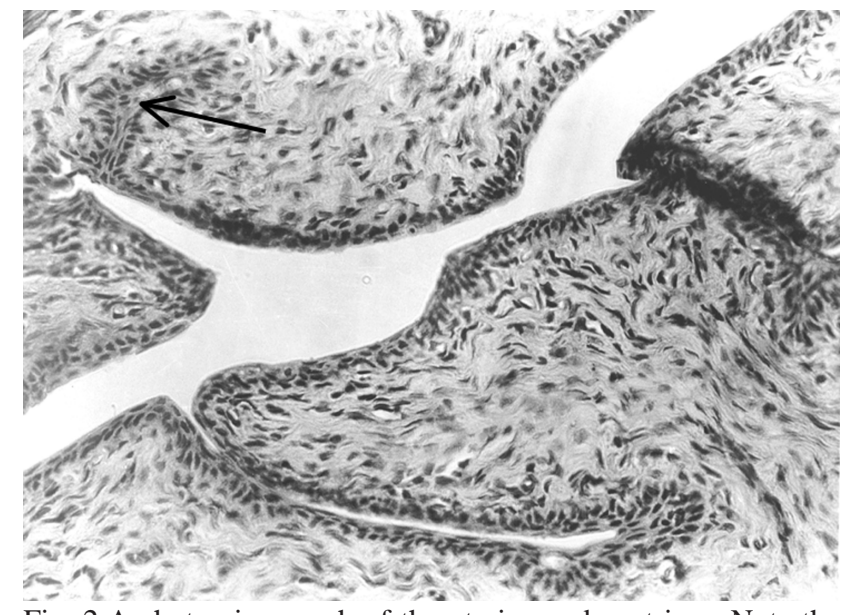

Fig. 2 A photomicrograph of the uterine endometrium. Note the folds with a pseudostratified epithelium and a uterine gland with a collapsed lumen (arrow). X 400. H-E stain.

Histologically the uterus exhibits the typical 3 layered structure (i.e. the endometrium, the myometrium and the perimetrium that is characteristic of other mammals. The endometrium in the non-pregnant uterus has scarce and atrophied uterine glands (Fig. 2), some of which have collapsed lumen. The uterine gland cells in the non-pregnant uterus had scanty cytoplasm and there cell sizes were about 10 micrometers in size (Fig. 2).

The earlier stage of development obtained is represented by figure 3 . The pregnant uterine horn is recognizable by a single locular swelling. The blastocyst is centrally implanted and the depth of implantation is superficial with the uterine epithelium remaining intact. The trophoblasts form a simple cuboidal to columnar epithelium (Fig. 3). The trophoblast and uterine epithelium are apposed to each other forming an epithliochorial placenta. 


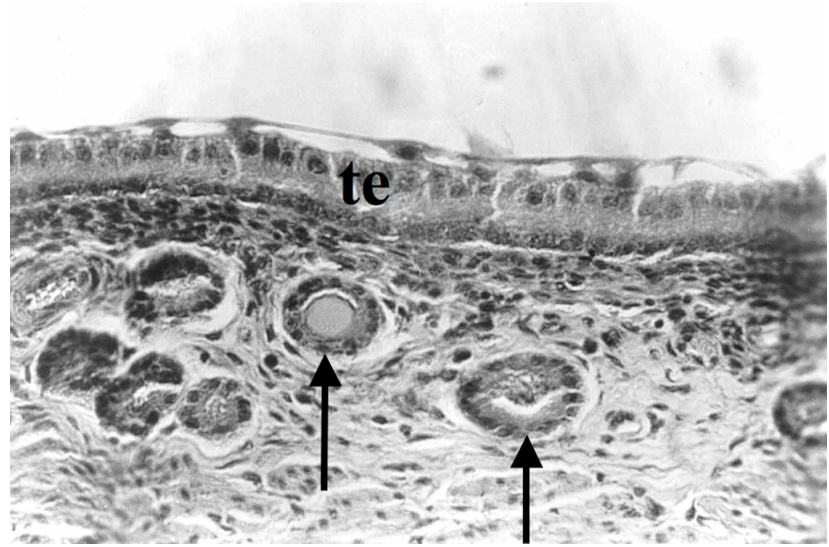

Fig. 3. A photomicrograph showing a section of the earliest stage of development. te - trophoblast epithelium, arrows - uterine gland profiles. X 200. H-E stain.

In the later stage pregnancy (third trimester) specimen, the glands undergo hypertrophy and hyperplasia and are found opposite foetal membrane structures known as chorionic vesicles (Fig. 4). Tubular uterine glands appear in cross section on semi thin sections (Fig. 5). Uterine glandular epithelium consists of cuboidal or columnar epithelial cells. These have abundant flattened cisternae of granular endoplasmic reticulum. Their nuclei have abundant euchromatin relative to the amount of heterochromatin. They also have a prominent Golgi apparatus, moderate numbers of secretory granules and multivesicular bodies. Both elongate and circular mitochondria are observed interspersed between long cisternae of granular endoplasmic reticulum (Figs. 6, 7 and 8 ). Their apical membranes are modified into numerous small

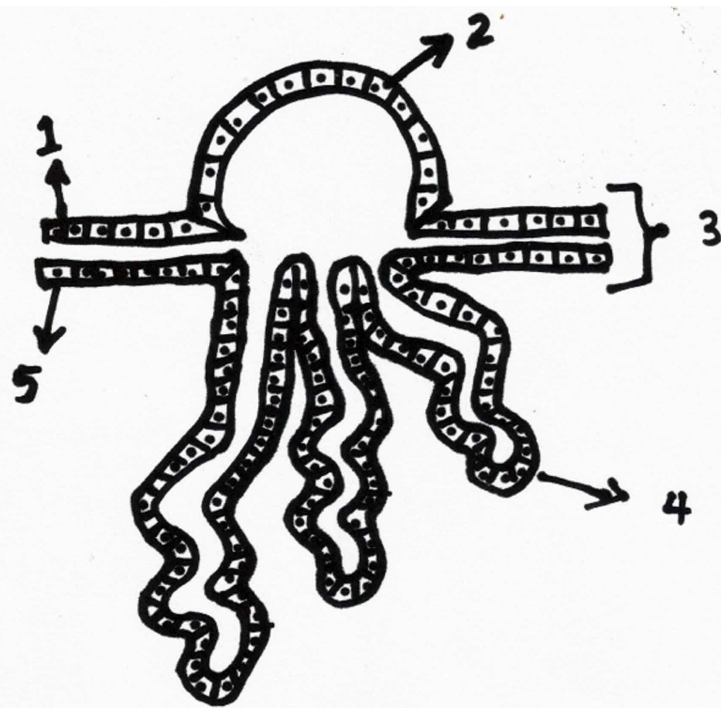

Fig. 4. An illustration of the spatial organization of the uterine glands opposite the chorionic vesicles. 1. Trophoblast epithelium, 2. Chorionic vesicle epithelium, 3. Contact membrane; formed by the trophoblast epithelium and the Uterine epithelium (epitheliochorial placenta), 4. Uterine gland epithelium, 5. Uterine epithelium.

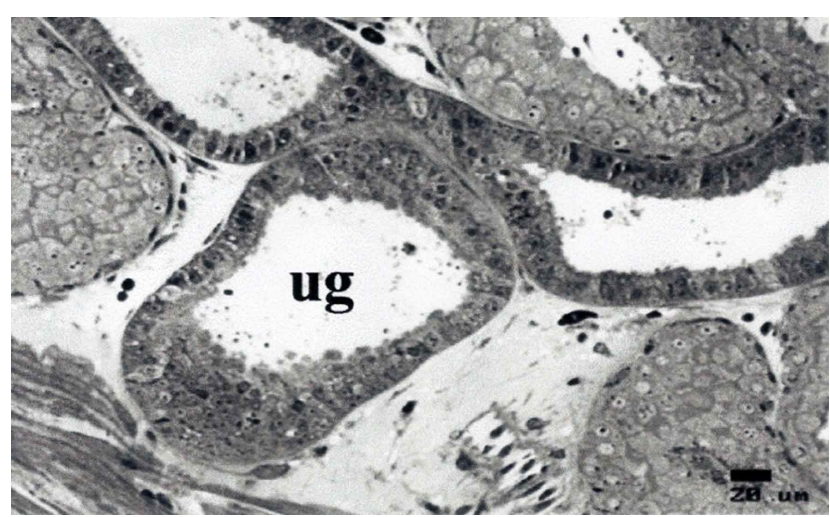

Fig. 5. A photomicrograph of the profiles of the uterine glands (ug). Methylene blue stain.

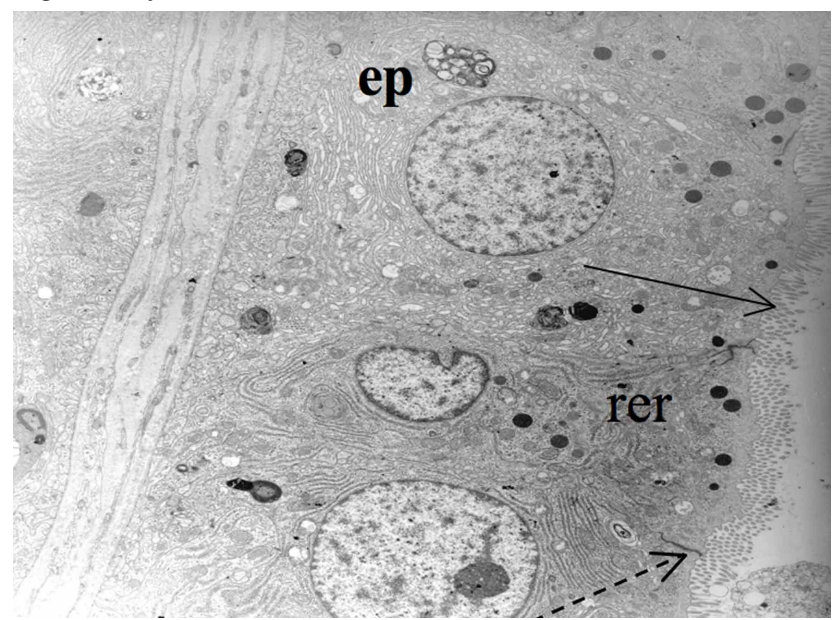

Fig. 6. An electron micrograph of maternal glandular epithelial cells (ep). Note the abundant flattened cisternae of granular endoplasmic reticulum (rer) and the numerous apical villi (solid arrow). Note the tight junctions between neighboring cells (dashed arrow) X 2500.

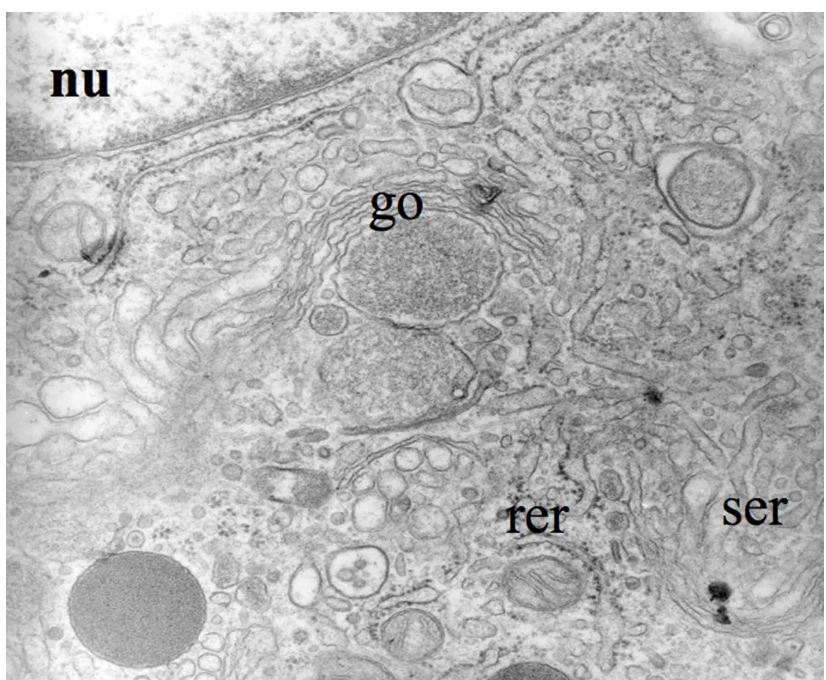

Fig. 7 An electron micrograph showing the structural details of the nucleus (nu) and the apical and supranuclear cytoplasm of a maternal glandular epithelial cell. Note the abundant granular (rer) and agranular endoplasmic reticulum (ser) and a well-developed Golgi complex (go). X 20.000. 


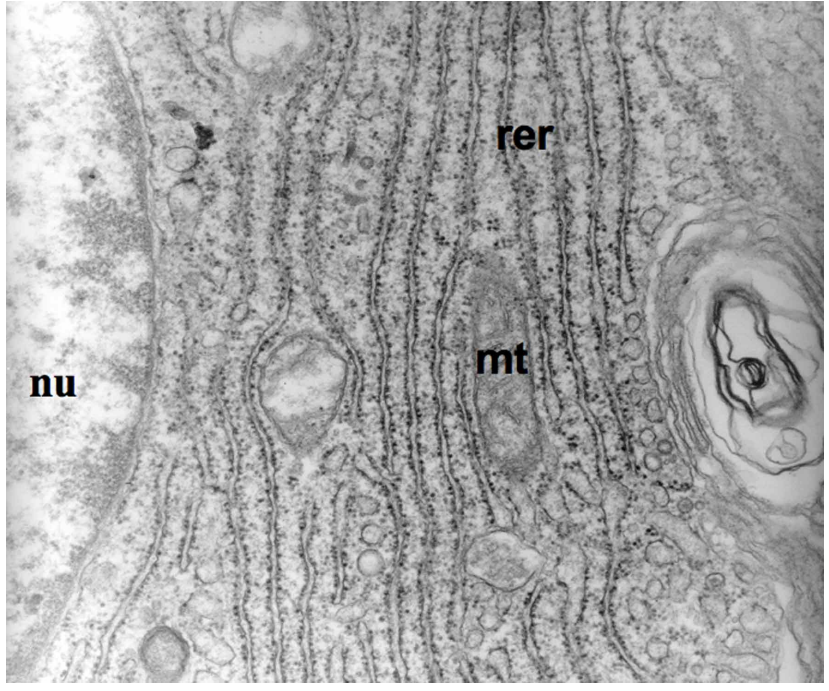

Fig. 8. An electron micrograph of a maternal glandular epithelial cell showing the flattened and abundant granular endoplasmic reticulum (rer), with mitochondria interspersed in between $(\mathrm{mt})$. The nucleus (nu) has both euchromatin and heterochromatin. X 20.000 .

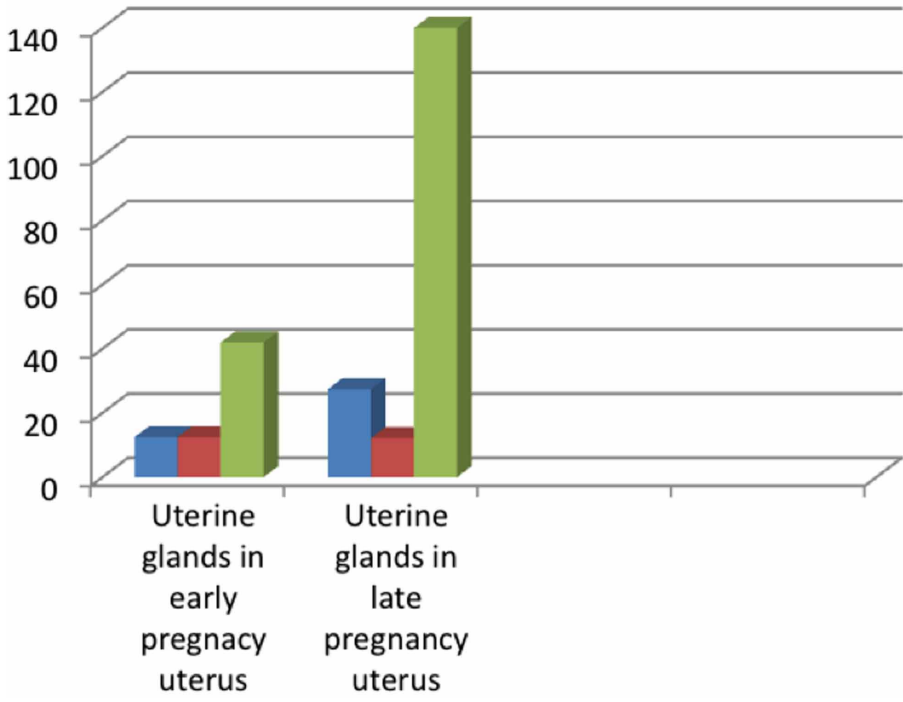

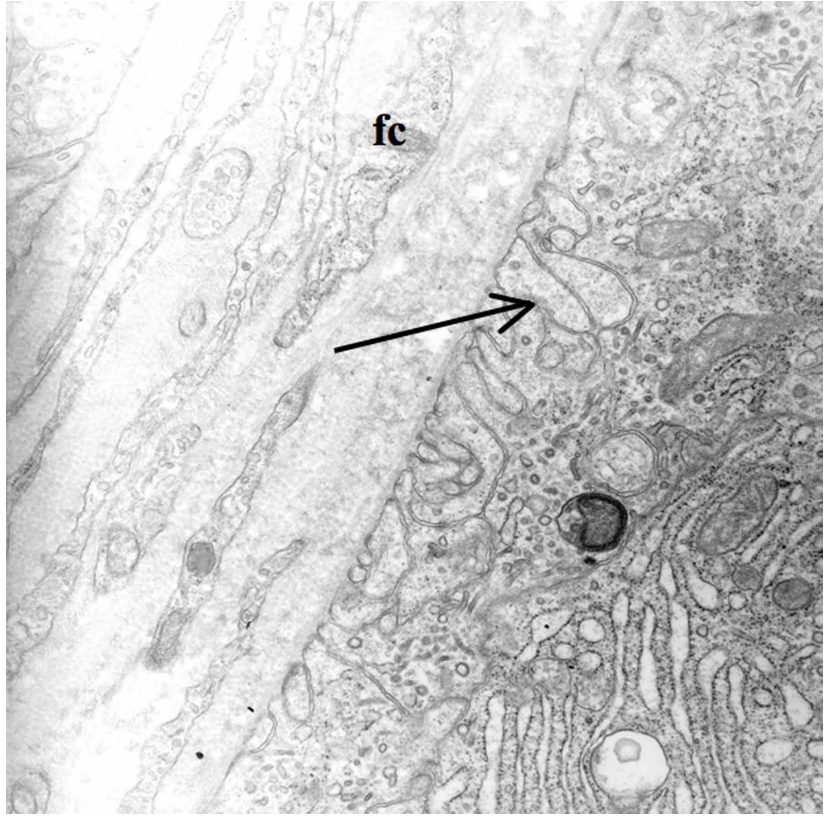

Fig. 9. An electron micrograph of the basal lamina just beneath the uterine gland epithelium. Note the infoldings of the basement membrane (arrow) and fusiform cells(fc) within the connective tissue below the basal lamina. X 10.000 .

\section{Average cell Height (micrometers) \\ Average cell Width/Diameter (micrometers) \\ Average lumen Diameter (micrometers)}

Fig. 10. Height and Width/ Diameter Averages of Uterine gland epithelial cells at different stages of pregnancy.

microvilli, tight junctions are present between the cells just below the surface and below the tight junctions, the lateral cell membranes are closely apposed (Fig. 6).

The epithelium rests on a basal lamina. Smooth muscle cells are also part of this wall and are found interspersed within the connective tissue below the basal lamina. The basement membranes of the uterine gland cells have numerous infoldings that in effect increase its surface area (Fig. 9).
Morphometric counts and measurements demonstrate an increase in both sizes and numbers of the uterine gland cells from non-pregnant to early pregnancy to advanced pregnancy. The average cell diameter does not show any change with advancement with pregnancy age. The average cell heights show an increase with advancement of pregnancy age (see Table I and Fig. 10). Average cell count numbers per profile of uterine gland show a marked increase as is seen in Table II and Fig. 11. Lumen diameters also show marked widening (Table I and Fig. 11). 


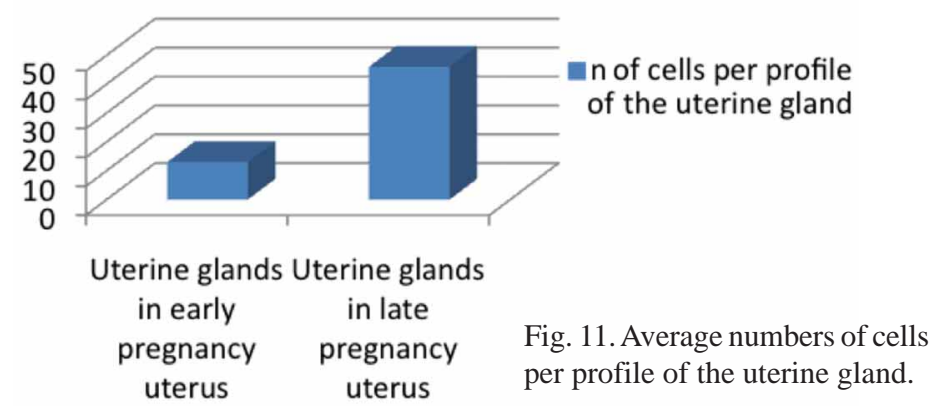

Table I. Averages on Height and width/Diameter of uterine gland cells at different stages of pregnancy.

\begin{tabular}{lccc}
\hline & $\begin{array}{c}\text { Average cell Height } \\
\text { (micrometers) }\end{array}$ & $\begin{array}{c}\text { Average cell } \\
\text { Width/Diameter } \\
\text { (micrometers) }\end{array}$ & $\begin{array}{c}\text { Average lumen Diameter } \\
\text { (micrometers) }\end{array}$ \\
\hline Uterine glands in early pregnancy uterus & 12.5 & 12.5 & 42 \\
Uterine glands in late pregnancy uterus & 27.5 & 12.2 & 140 \\
\hline
\end{tabular}

Table II. Average numbers of cells per profile of the uterine glands

\begin{tabular}{lc}
\hline & $\begin{array}{c}\text { Average } \mathbf{n} \text { of cells per } \\
\text { profile of the Uterine glands }\end{array}$ \\
\hline Uterine glands in early pregnancy uterus & 13 \\
Uterine glands in late pregnancy uterus & 46 \\
\hline
\end{tabular}

\section{DISCUSSION}

The uterine glands in the non-pregnant lesser galago are scarce and where present are reduced in size and have a collapsed lumen. The ultrastructural characteristics of the uterine glands in the pregnant lesser galago suggest active synthesis, packaging and secretory activity due to the presence of extensive rough endoplasmic reticular system and a well-developed Golgi apparatus (Okada et al., 1994). Presence of smooth muscle cells in the wall of the glands suggests active expulsion of secretion from the lumen of the glands. The location of the uterine glands opposite the chorionic vesicles is strategic in that the two structures combine to form an efficient and direct route through which the developing fetus gets adequate nutrients (histiotrophe) from the mother. Provision of adequate nutrition to a fetus is the key to a successful pregnancy. The uterine glands are an important source of nutrients to the human fetus during organogenesis, when metabolism is essentially anaerobic (Burton et al., 2002). Histiotrophe is the nutritional material accumulated in spaces between the maternal and fetal tissues, derived from the maternal endometrium and the uterine glands. The uterine glands synthesize and secrete substances essential for survival and development of the embryo or fetus (Gray et al., 2001). These include nutrients and growth factors that modulate the growth of the embryo (Hempstock et al., 2004).
Infoldings of the basement membrane, of the uterine gland cell as observed in this study, has been observed in the salivary gland of the mouse (Pícoli et al., 2011). It is inferred that, coupled with the abundant mitochondria, the increase in this surface area provides for effective uptake of necessary macromolecules that go to form the secretion released from the apical surface.

This study demonstrates a definite increase in the number of cells that surround each glandular profile. This physiologic hyperplasia is necessary as the demand for nutrients by the fetus increases. It has been demonstrated in the pig as a result of stimulation by the hormone progesterone (Roberts \& Bazer, 1988; Bailey et al., 2010). However an increase in uterine gland cell numbers may also be a sign of abnormal changes, as is the case in precancerous changes of endometrial carcinomas in women (Wang et al., 2005). The study also demonstrates hypertrophy of the uterine gland cells. Even though the average cell diameter does not show any change with advancement with pregnancy age; average cell heights show an increase with advancement in pregnancy age. The net effect is such that there is a net increase in volume as volume is a function of both the diameter and the cell height. It is inferred that the increase in the cell sizes is a result of an increase in cellular organelles that take part in the secretory function of these cells. 
NJOGU, A.; OWITI, G. O. \& ODUOR-OKELO, D. Microestructura de la glándula uterina en la gálago menor (Galago senegalensis) preñada y no preñada. Int. J. Morphol., 31(2):771-776, 2013.

RESUMEN: La histología y ultraestructura de las glándulas uterinas de la gálago menor (Galago senegalensis) fueron estudiadas en seis ejemplares (5 preñadas y 1 no preñada). Una parte de las glándula se fijó con Bouin y otra con glutaraldehído al 2,5\% en tampón cacodilato 0,1 M. Una visión general de los principales resultados reveló que las glándulas uterinas en el útero no gestante son rudimentarias y escasas dentro de la mucosa. Al principio de la preñez (primer trimestre) las glándulas uterinas aparecen en racimos. En la última etapa de la preñez (tercer trimestre) las glándulas uterinas aparecen opuestas a las vesículas coriónicas. En las últimas etapas de gestación el epitelio glandular materno consiste principalmente en epitelio cilíndrico simple. Las células tenían abundantes cisternas aplanadas en el retículo endoplásmico rugoso, por lo general con una orientación apico-basal. Sus núcleos tenían abundante eucromatina en relación con la cantidad de heterocromatina. También tenían un aparato de Golgi prominente bastante característico de células que sintetizan proteínas. El plasmalema basal fue rechazado en repliegues que psoeen el efecto de aumentar el área de superficie a través del cual los nutrientes podrían pasar desde la circulación materna y son secretadas por las célula como histiotrofo. Hipertrofia fisiológica e hiperplasia de las glándulas uterinas se observaron con el avance de la preñez.

PALABRAS CLAVE: Gálago menor; Glándulas uterinas; Microestructura.

\section{REFERENCES}

Bailey, D. W.; Dunlap, K. A.; Frank, J. W.; Erikson, D. W.; White, B. G.; Bazer, F. W.; et al. Effects of long-term progesterone on developmental and functional aspects of porcine uterine epithelia and vasculature: Progesterone alone does not support development of uterine glands comparable to that of pregnancy. Reproduction, 140(4):583-94, 2010.

Beck, F. Comparative Placental morphology and function. Environ. Health Perspect., 18:5-12, 1976.

Bevilacqua, E.; Hoshida, M. S.; Amarante-Paffaro, A.; Albieri-Borges, A. \& Zago Gomes, S. Trophoblast phagocytic program: roles in different placental systems. Int. J. Dev. Biol., 54(2-3):495-505, 2010.

Burton, G. J.; Watson, A. L.; Hempstock, J.; Skepper, J. N. \& Jauniaux, E. Uterine glands provide histiotrophic nutrition for the human fetus during the first trimester of pregnancy. J. Clin. Endocrinol. Metab., 87(6):2954-9, 2002.

Burton, G. J.; Jauniaux, E. \& Charnock-Jones, D. S. Human early placental development: potential roles of the endometrial glands. Placenta, 28 Suppl. A:S64-9, 2007.

Gray, C. A.; Bartol, F. F.; Tarleton, B. J.; Wiley, A. A.; Johnson, G. A.; Bazer, F. W.; et al. Developmental biology of uterine glands. Biol. Reprod., 65(5):1311-23, 2001.

Hempstock, J.; Cindrova-Davies, T.; Jauniaux, E. \& Burton, G. J. Endometrial glands as a source of nutrients, growth factors and cytokines during the first trimester of human pregnancy: A morphological and immunihistochemical study. Reprod. Biol. Endocrinol., 2:58, 2004.

Jones, C. J.; Aplin J. D. \& Burton, G. J. First trimester histiotrophe shows altered sialylation compared with secretory phase glycoconjugates in human endometrium. Placenta, 31(7):57680, 2010.
King, B. F. The fine structure of the placenta and chorionic vesicles of the Senegal bush-baby, Galago crassicaudata. Am. J. Anat., 169(1):101-16, 1984.

Latham, K. E.; Kutyna, K. \& Wang, Q. Genetic variation in trophectoderm function in parthenogenetic mouse embryos. Dev. Genet., 24(3-4):329-35, 1999.

Njogu, A.; Owiti, G. O.; Persson, E. \& Oduor-Okelo, D. Ultrastructure of the Chorioallantoic placenta and chorionic vesicles of the lesser bush baby (Galago senegalensis). Placenta, 27(6-7):771-9, 2006.

Okada, H.; Merryman, J. I.; Rosol, T. J. \& Capen, C. C. Effects of humoral hypercalcemia of malignancy and gallium nitrate on thyroid $\mathrm{C}$ cells in nude mice: immunohistochemical and ultrastructural investigations. Vet. Pathol., 31(3):349-57, 1994.

Pícoli, L. C.; Dias, F. J.; Issa, J. P.; Ogawa, K.; Ciena, A.; Iyomasa, M. M.; et al. Ultrastructure of submandibular salivary glands of mouse: TEM and HRSEM observations. Microsc. Res. Tech., 74(12):1154-60, 2011.

Roberts, R. M. \& Bazer, F. W. The functions of uterine secretions. J. Reprod. Fertil., 82(2):875-92, 1988.

Wang, M. Q.; Zhang, Q. H.; Guo, L. L.; Cai, Y. R. \& Wang, Y. Pathologic diagnosis of endometrial carcinoma in curettage specimens in women under forty years of age. Zhonghua Bing Li Xue Za Zhi., 34(5):262-5, 2005.

Wooding, F. B. P. \& Burton, G. J. Comparative Placentation: Structures, Functions and Evolution. Berlin Heidelberg, SpringerVerlag, 2008. pp.17-20, Chapter 1.4.6.

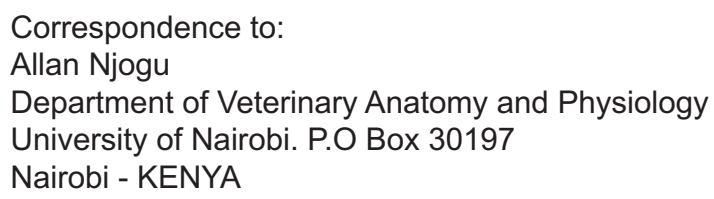

Email: njogua@uonbi.ac.ke

Received: 13-09-2012

Accepted: 25-02-2013 